
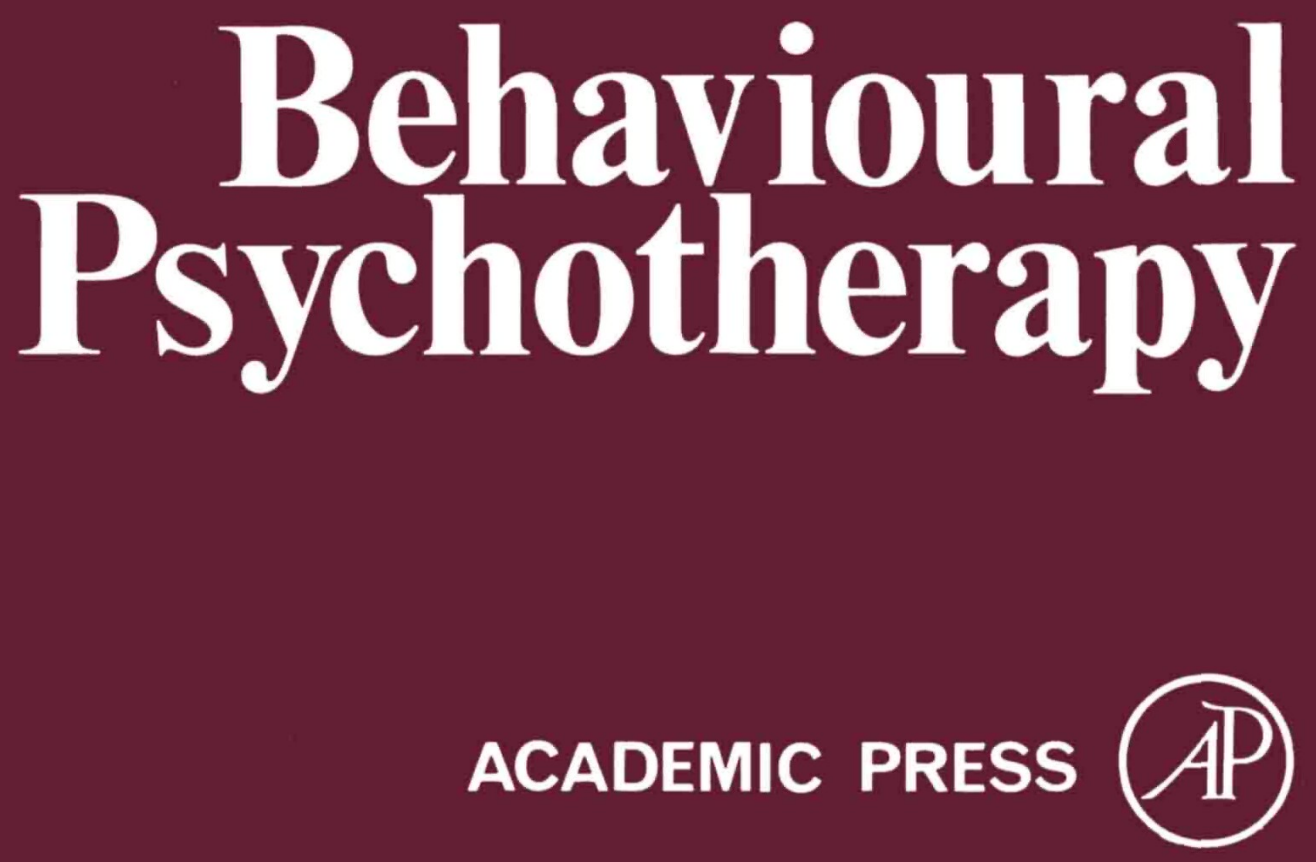

A Subsidiary of Harcourt Brace Jovanovich, Publishers

London New York Toronto Sydney San Francisco 


\section{Behavioural Psychotherapy}

AN INTERNATIONAL MULTIDISCIPLINARY JOURNAL FOR THE HELPING PROFESSIONS

\section{EDITORS}

Ray Hodgson

William Yule
Addiction Research Unit, Institute of Psychiatry, London, U.K. Department of Psychology, Institute of Psycbiatry, London, U.K.

\section{ASSOCIATE EDITOR (U.S.A.) \\ G. Terence Wilson Graduate School of Applied and Professional Psychology, Rutgers University, Piscataway, New Jersey, U.S.A.}

\section{CORRESPONDENCE}

Howard Rankin

Institute of Psychiatry, London, U.K.

\section{BOOK REVIEWS}

Sue Spence

\section{EDITORIAL BOARD}
Kelly Brownell
Department of Psychiatry, University of Pennsylvania. Pbiladelphia, U.S.A.
Iver Hand
Isaac Marks
Psychiatrische und Nervenklinik, Universität Hamburg, West Germany.
John Marzillier
Department of Psychiatry, Institute of Psycbiatry, London, U.K.
Andrew Matthews
Department of Psychology, University of Birmingham, U.K.
Department of Psychology, St George's Hospital, Tooting, London, U.K.

\section{EDITORIAL ADVISORY BOARD 1981-1982}

Joe Connolly (U.K.), Edward Craighead (U.S.A.), Paul Emmelkamp (The Netherlands), K. Gunnar Gotestam (Norway), Barbara Hudson (U.K.), David Horne (Australia), Derek Jehu (Canada), Phillip Kendall (U.S.A.), Yves Lamontagne (Canada), Peter Lindsey (U.K.), Bill Marshall (Canada), Jim Orford (U.K.), Jack Rachman (U.K.), Sten Ronnberg (Sweden), Bob Sanson-Fisher (Australia), Gudrun Sartory (U.K.), Alison Tierney (U.K.).

Published quarterly (January-October) at 24-28 Oval Road, London NW 1 7DX, England, by Academic Press Inc. (London) Limited. Volume 9, four issues: inland $£ 17.00$ including postage; abroad $\$ 49.00$ including postage. Subscription orders should be addressed to Academic Press Inc. (London) Limited, 24-28 Oval Road, London, NW1 7DX except for those originating in the U.S.A., Canada and Central and South America, whicin should be addressed to Academic Press Inc., 111 Fifth Avenue, New York, New York 10003 , U.S.A. Send notices of change of address to the office of the Publishers at least 6-8 weeks in advance. Please include both old and new addresses. Postmaster send changes of address to: Bebavioural Psychotherapy, 111 Fifth Avenue, New York, New York 10003, U.S.A. Application to mail at second-class postage rates is pending at Jamaica, New York 11431, U.S.A. Air freight and mailing in the U.S.A. by Publications Expediting Services Inc., 200 Meacham Avenue, Elmont, New York 10003.

(C) 1981 British Association For Behavioural Psychotherapy. The appearance of the code at the bottom of the first page of a paper in this journal indicates the copyright owner's consent that copies of the paper may be made for personal or internal use, or for the personal or internal use of specific clients in the U.S.A. This consent is given on the condition within the U.S.A. that the copier pay the stated per-copy fee through the Copyright Clearance Center, Inc., 21 Congress Street, Salem, MA 01970, U.S.A. for copying beyond that permitted by Sections 107 or 108 of the U.S. Copyright Law. This consent does not extend to other kinds of copying, such as copying for general distribution, for advertising or promotional purposes, for creating new collective works for resale or for copying or distributing copies outside the U.S.A. 


\section{CONTENTS}

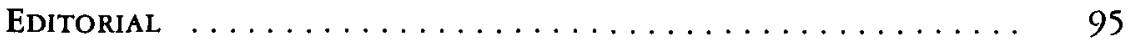

BlackBuRn, I. M. AND BISHOP, S. Is There an Alternative to Drugs in the Treatment of Depressed Ambulatory Patients? ......... 96

Ballard, M. AND Yule, W. A case of Separation Anxiety Treated by in vivo Systematic Desensitization ................ 105

LAws, D. R. AND O'NeIL, J. A. Variations on Masturbatory Condi-

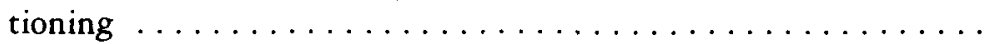

Marks, I. Behavioural Concepts and Treatments of Neuroses ....

WILsON, G. T. Behavioural Concepts and Treatments of Neuroses : Comments on Marks ..................... 155

Masterson, J. F., Earls, H. and TAYlor, D. The Effects of Instructions and Reinforcement on the Handwriting of a 13-YearOld Child in a Remedial School $\ldots \ldots \ldots \ldots \ldots \ldots \ldots \ldots$

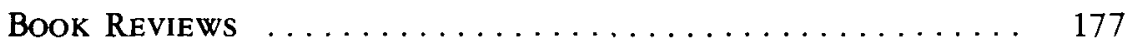

ANNOUNCEMENT $\ldots \ldots \ldots \ldots \ldots \ldots \ldots \ldots \ldots \ldots \ldots \ldots \ldots$ 


\section{Behavioural Psychotherapy}

The journal, Behavioural Psychotberapy, has grown naturally out of the Bulletin of the British Association for Behavioural Psychotherapy (B.A.B.P.) and is now read by a large cross-section of the helping professions, including psychologists, psychiatrists, nurses, teachers, social workers, counsellors and general practitioners. Our Editorial Advisory Board represents this wide spread and we hope that we can continue to attract articles having some relevance to all of these groups.

The scope of the journal is very broad. We will consider articles relevant to most areas of human behaviour and human experience which would be of interest to members of the helping and teaching professions. Typical areas covered by the journal are:

* Cognitive-behavioural approaches to therapy

* Experimental testing and methodology

* Behavioural assessment

* Psychological theory

* Application of concepts derived from experimental and social psychology

* Self-help and self-control

* Biofeedback and behavioural medicine

* Behavioural psychotherapy with children

* Prevention

* Theoretical and philosophical considerations.

Behavioural psychotherapy is an applied science, so we must expect that the concepts, methodology and techniques will change rapidly in the future. The journal will try to reflect and influence these changes.

\section{About B. A. B.P.}

The British Association for Behavioural Psychotherapy was founded in 1972. It is a multi-disciplinary organization and full membership is open to members of the helping professions - psychologists, psychiatrists, social workers, nurses, probation officers, teachers etc. The objects of the Association are to promote the advancement of the theory and practice of behavioural psychotherapy, to provide a forum for discussion, to disseminate information, to liaise with public and professional bodies, to promote research and to assist in training.
B.A.B.P. Membership Secretary
Mr H. W. Lomas, Craig House, Bank Street, Bury BL9 0BA, U.K. 